\title{
The Role and Status of Research: The Case of Ethiopian Higher Institutions
}

\author{
Wubalem Girma Giday, Itishri Sarangi
}

\begin{abstract}
Research in the higher institutions' for certain countries plays a vital role in promoting and resolving the nations' problem by engaging its faculty members in different demand driven researches by prioritizing various thematic areas. Ethiopia has additionally been occupied with a profoundly goal-oriented exertion utilizing inquires about to adjust its advanced education framework by making joins in more straightforward help of its national procedure for monetary development and destitution decrease. This study identified the role and status of research in HEIs in Ethiopia since 2016-2018. Employing a quantitative content analysis of the quality audit reports produced based on one of the 10 quality focus areas delineated for research and outreach activities using a series of interviews, analyzed documents and visited teaching- learning resources, infrastructures and observed activities. Sampling that is availability sampling employed from all 20 (9 government and 11 non- government institutions) audited HEIs from 2016-2018. Results indicate that there are factors that are affecting research activities and output in the audited HEIs such as too much load of work given to teachers lack or shortage of budget in both government and non-government HEIs, lack of clarity in the legislation, inadequate awareness on the part of some of the academic staff that their promotion is dependent on doing researches and publishing and the likes. Furthermore, the study revealed that no clear information as to how researches are approved, and how budget is allocated in the government HEIs, inadequate research writing knowledge and skill in some young researchers and inability to launch research journals both in government and non government HEIs. Recommendations for decision and policy makers, controllers, and pioneers of advanced education establishments incorporate guaranteeing proper funds and human resource development should be in place, efficient managers and management systems, and clear research policy should be set in proper manner.
\end{abstract}

Keywords : Ethiopia, higher education institutions, research, government.

\section{INTRODUCTION}

The roles of Higher Education Institute (HEIs) are to make and spread knowledge and information; that is, to research and instruct. To the extent that the formation of learning bases in significant control zones is an aggregate endeavor of mankind, HEIs should essentially be worldwide in their introduction the idea of logical progression is that the present research expands upon the revelations of others, wherever on the planet they have been made (Healey, 2008).

Incomprehensive methodologies in current quality confirmation practice in light of the developing worry on

Revised Manuscript Received on July 22, 2019.

Wubalem Girma Giday, Lecturer, Wolaita Sodo University, Ethiopia Ph.D Scholar at KIIT -DU,Bhubaneswar, India

Prof. Itishri Sarangi, School of Humanities, KIIT -DU, Bhubaneswar, India instructive quality, Ethiopia displayed the demonstration of significant worth certification to its propelled training at both the national and institutional measurements with the help of genuine declarations. At the national measurement, the Higher Education Proclamation (FDRE, 2003) made courses of action for the establishment of the Higher Education Relevance and Quality Agency (HERQA) whose objective is to rehearse the request of protecting and improving the quality and congruity of cutting edge training in the country (FDRE 2003, Article 78-85) cited in Abebe, T. R. (2015). In the course of the most recent decade, the office has been dealing with accreditation licenses, assessing execution reports, directing norms of foundations, and assembling and dispersing data on the status of value.

At the HEI's stage, the most significant legitimate structure that laid the foundation for quality upgrade was the 2009 Higher Education Proclamation (FDRE, 2009). HEI's needed the foundation of a constantly improving and solid inner framework for the best improvement at each institution (FDRE 2009, Article 22) cited in Abebe, T. R. (2015). In that manner HEI's were encouraged by the understanding that numerous of them the nation had failed behind in creating quality affirmation methodologies and setting up productive frame. The practice of the declaration was a grand advance in the historical backdrop of value affirmation in the HEI'S expected to maintain more quality implementation notwithstanding the transcendently outer one.

In addition to these, activities to be done by HERQA is maintaining and assuring quality researches in Higher Education Institutes (HEI's) and these researches mostly can be done in HEI's as it is one of its pillars. All Ethiopian HEI's have policy premises on research publications. Among these are: "research is an essential component of the university functions. Academic units, research institutes and centers should work hand in hand for the purpose of offering quality education, training and advancement of knowledge in various disciplines that are relevant to the development needs of the country. Research at the university is expected to contribute to capacity building and continued growth of the university, the development of arts, science and technology as well." Another policy premise is "although the primary responsibility of teaching faculties is in the area of training, research is an integral part of their activities since Academic Staff members in teaching Schools/departments are expected to devote $25 \%$ of their time to research. Conversely, staff members of research institutes are expected to have a home base in an academic department where they may be expected to devote $25 \%$ of their time to teaching depending upon the nature of the program or department." In addition to these, the university will attempt to manufacture its own ability to distribute showing materials, books, course readings and references and request look into 
subsidizing and also research discoveries ought to be spread through distributions explore papers, books and periodicals, introduction of intermittent papers and support and lead of classes, symposia and workshops, and so forth.

\section{The purposes of the study}

Aiming at:

- examining the variables that contribute for the poor performance of research activities in government and non-government higher education in Ethiopia.

- identifying differences between government and non-government HEIs in the type and factors that negatively affect their research outputs

- forwarding some recommendations.

\section{Procedures for Initiating and Conducting Research in Higher Education Institutes}

The role of HEI's is the present world enormous, perplexing and imperative. A wide scope of difficulties and openings is developing, with numerous political, financial and social ramifications. Maybe most critical are the difficulties related with moving viewpoints of learning itself, which are firmly affecting the job and the obligation of colleges in the public arena. Colleges are very much situated to interface the neighborhood and the worldwide and this gives them impressive access to and impact over change process in the social orders. It might upgrade their capability to add to human and social advancement through the advancement and assistance of native cooperation and inclusion in these procedures.

Universities legislation stated that "any research and development proposal initiated by an academic staff for which internal or external funding is sought shall be submitted to the School/Department's Research and Development Committee (RDC) for review and then approval by the School/Department Council. Academic staff carrying out research without the need for financial support shall also have their research project endorsed by the respective school/departments. The modalities of initiation, review, endorsement and approval of research proposals at the various levels as well as incentive mechanisms and modalities for termination shall be issued in the form of guidelines by the decision of universities legislation (Wolaita Sodo University, 2016)."

\section{Objectives of Ethiopian Higher Education (HEP 650/2009, Article 4)}

HEIs should "promote and enhance research focusing on knowledge and technology transfer consistent with the country's priority needs, ensure that education and research promote freedom of expression based on reason and rational discourse and are free from biases and prejudices"; and the HEIs shall: "uphold the objectives of higher education and the guiding values of the institution; and ensure that it is an institution of scholarship; develop programmes of study and provide higher education; prepare and supply qualified graduates in knowledge, skills, and attitudes on the basis of needs of the country; and award academic qualifications in accordance with its programmes; and undertake and encourage relevant study, research, and community services in national and local priority areas and disseminate the findings as may be appropriate; undertake, as may be necessary, joint academic and research projects with national and foreign institutions or research centers (HEP650/2009, Article 8, 1-3)."

According to Ethiopian Higher Education (HEP650/2009, Article 24),

- "Trinity of purposes" of higher education-
a. teaching,
b. research and
c. outreach services. (Clark (1986) cited in Kassahun K. (2018)

\section{How are education and research linked?}

As higher education institutions are meant to meet the needs of all their stakeholders (the fact that quality is understood differently by different stakeholders) will put them in a difficult position. So they will have to negotiate between the needs of their stakeholders and translate them into vision, missions and goals and objectives which will be achieved through the implementation of the three major activities of a higher education institution:

\section{Teaching/learning}

According to Saint (2004), "An academic staff of the HEI's is required to be a scholar with full devotion to the advancement of the frontiers of knowledge in accordance with the best traditions developed by scholarly circles throughout the world. It shall be the primary duty of the academic staff to carry out functions in the best interest of the University and the nation having due regards to professional etiquette." The set of working responsibilities for scholastic staff conveys the desire that they burn through 25 percent of their time in research exercises. Throughout the years, Ethiopian scholastics have delivered a considerable collection of research on farming, building innovation, wellbeing sciences, regular sciences, sociologies, and instruction archived.

A scholarly staff of the HEI's will configuration create and execute course material in an area of specialization following built up universities strategies so that the course material might be conveyed over the whole semester in a reasonable manner. What's more, the scholastic staff ought to likewise regard the constitution and advanced education announcement of the nation, and enactments of their regarded the universities and other appropriate laws of the nation. Then again, Academic staff attempts to manufacture its own ability to distribute showing materials, books, course readings and references and request investigate financing.

\section{Research}

Academic staff is required to lead critical thinking research that adds to the headway of learning or has direct effect on network advancement. In deciding their examination needs, the foundations' will consider: the extent of the exploration issue, the necessities and needs of the locale and nation; need regions laid out in the exploration procedure of the university's; missions and goals, and the university on the loose. 


\section{Outreach}

Researches discoveries ought to be scattered through productions research papers, books and periodicals, introduction of infrequent papers and investment and lead of courses, symposia and workshops, and so on.

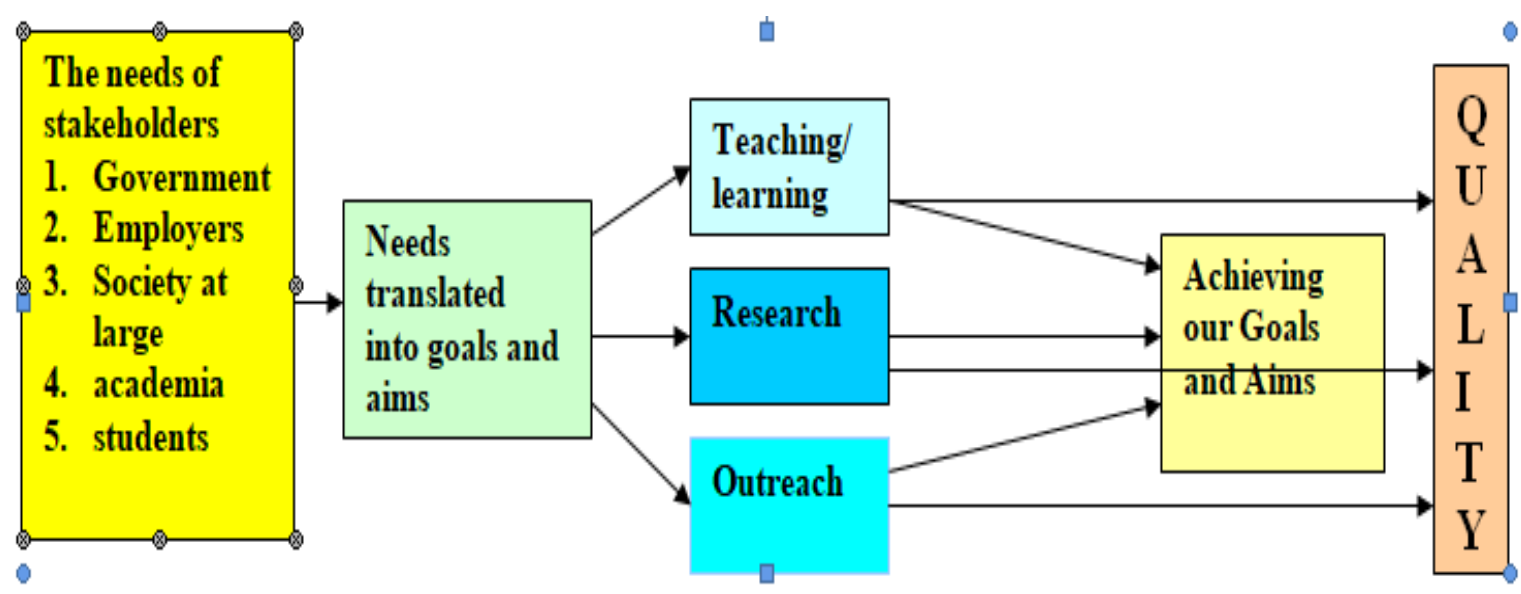

\section{METHODOLOGY}

The paper used a quantitative content analysis of the quality audit reports produced based on one of the 10 quality focus areas delineated for research and outreach activities. The reports are the result of a series of interviews, analyzed documents and visited teaching- learning resources, infrastructures and observed activities.

Sampling techniques i.e. availability sampling was employed so as to get data from all 20 universities ( 9 government and 11 non government) and using the audit report from 2016-2018 have been taken from HEIs for the study.

Populations of the study were from $1^{\text {st }}$ generation two universities, from $2^{\text {nd }}$ generation seven universities, and from private universities eleven universities were selected that have more than 5 years old in teaching and learning.

\subsection{East African Universities}

According to Oyewole (2009), African nations and other least created nations could utilize learning to limit the pay hole among them and the created world economies. Higher education (HE) is a significant establishment that these nations should create and improve so as to address this difficulty.

Basic for Africa's future is fortifying indigenous instructive frameworks and establishments for producing and applying information by guaranteeing long haul open help with accentuation on research limit. Notwithstanding singular abilities created in research work, examine limit incorporates: nature of the exploration condition, financing, sufficient foundation, inquire about motivating forces, time accessible to the scientist, and so on.

Sawyerr (2004) depicted that "in most African nations, conditions for research have been seriously traded off as show by the for the most part poor compensation, overwhelming showing loads, failure to coach youthful staff, and deficient foundation." Recently there is a decline in research activities in "virtually all the prestigious east African universities like Nairobi and Makerere in East Africa' and some of the factors are: lack of funding and lack of adequate qualified researchers.

HEIs in Ethiopia are at present encountering a quick change. There is a growing affirmation of the activity of cutting edge instruction to the money related and social difference in the country. This is reflected in the present government's undertakings to expand preparing when all is said in done and propelled instruction explicitly (Kahsay, 2012).

Advanced education is basic for the production of fundamental $\mathrm{HR}$, for instance, human services experts, legal advisors, engineers, directors, specialists, and scientists basic for financial improvement of a country. Besides, advanced education is middle for learning and abilities creation, adjustment and scattering. It likewise assumes a critical job in giving applicable and quality network and open administrations. Higher education is along these lines basic for monetary advancement, political strength and harmony, just as structure law based culture and firm social orders (Yizengaw, 2005).

According to Abebe (2015), missions of Ethiopian universities similar to their partners over the globe, Ethiopian universities are entrusted by the nation's advanced education declaration with the essential missions of undertaking instructing and learning, research and network administration.

\section{Research and Research Directions}

The focal point of research in any Ethiopian higher institutions will be on advancing the pertinence and nature of instruction and on the nation's advancement issues concentrating on exchange of innovation, characterize its center research territories and topics based on the need needs of the nation, the establishment's similar favorable circumstances, and in conference with the key partners.

All the more explicitly, every institution will attempt look into that will:

a. take into record the need needs of the nation and empower the nation to illuminate its difficulties and manufacture its ability through innovation exchange;

b. equip understudies with essential learning and aptitudes that empower them to attempt further and applicable investigations and research. 
Notwithstanding these, each HEI's strength have a systematized framework that empowers it to do arranged research and direct joint research ventures with other national and universal establishments, investigate focuses, and businesses and will have a straightforward arrangement of research that conveys intentionally its scholastic staff as basically instructors, analysts, or mixes thereof based on its examination motivation and plan, self evident legitimacy, and common sense, and with stipulations illuminating discussed areas.

In Ethiopian Higher Education Institutes there are different challenges that hinder the implementation of research quality:

- 'shortage of experienced ....academic staff,

- declining educational quality, and weak research output'(Saint, 2004)

- Lack of adequate qualified researchers

- $\quad$ lack of funding

- poor framework,

- $\quad$ high mind channel

- $\quad$ limited assets

- wastefulness in the utilization of accessible assets shortage of experienced doctorates among academic staff (Yizengaw, 2005). These problems in turn

- weak research output,

- $\quad$ limited publication by the students and staff, and

- weak research culture.

\section{MINIMUM REQUIREMENTS USED TO REVIEW THE INSTITUTION}

3.1 Indicators used while assessing institutions:

- proportion of academic staff engaged in research activities, publications, etc.

- Less than $1 \%=$ No

- Between $1 \%$ and $5 \%=$ low

- More than $5 \%=$ significant

- Availability of research policy and guideline

- Research budget for research, consultancy and community services Presence of community services (Kassahun K., 2018).

\section{FINDINGS}

The violently extending higher education framework in Ethiopia should be mindfully formed along the pathway of resulted in:

good quality research and its usage (Abebe, 2015). According to the findings of the study, the researcher drowns the following points as actors that are affecting research activities and output in the audited HEIs. There were:

$>$ Too much load of work given to teachers - willingly or unwillingly

$>$ Lack or shortage of budget in both government and non-government HEIs

$>$ Lack of clarity in the legislation - percentage of the teachers working ours they should spend on research

$>$ Inadequate awareness on the part of some of the academic staff that their promotion is dependent on doing researches and publishing.

$>$ Renewal of academic staff contract is not linked with research and publication as it is in the other foreign universities.

> In ability to clearly position the quality assurance officer on the organizational structure of the institution,

$>$ Inability to assign an RPO or if established multiple tasks will be given to the office and the officer in the Non government HEIs to minimize operational costs

$>$ no clear information as to how researches are approved, and how budget is allocated in the government HEIs

> Inability to launch research journals both in government and non government - the situation is severe in the non-government, almost non existent

$>$ Inadequate research writing knowledge and skill in some young researchers

\section{Some Recommendations}

1. Appropriate funds should be in place like

$>$ the HE proclamation should determine what percentage of the total institutional budget should go to research (now it is inconsistent some spend millions while others use nothing)

$>$ the provisions set for the RPO in government in the proclamation should also be implemented by the nongovernment too - like establishing a separate RPO, setting aside budget etc

$>$ develop effective project proposal writing to increase the sources of research funds

2. Human resource development

$>$ have a permanent platform where experienced researchers can share their experience to novice researchers

$>$ have capacity building in research areas as one of their duties

$>$ expanding alternative digital platforms where research outputs can be presented and reviewed and made available for implementations

$>$ strictly link promotion with research outputs (like renewal of contracts, publish or ...)

$>$ attach benefits with outputs 
use and encourage local languages to produce more researches (as in some cases language is the inhibitor)

3. Efficient managers and management systems

$>$ have managers who pay attention to the goals of and purposes of higher education through research activities.

4. Clear research policy should be set

\section{REFERENCES}

1. Abebe, R. T. (2015). Expanding quality assurance in Ethiopian higher education. Working Papers in Higher Education Studies, 1(2).

2. Clark, B. R. (1986). The higher education system: Academic organization in cross-national perspective. Univ of California Press.

3. FDRE. (2003a). Higher Education Proclamation (No. 351/2003). Addis Ababa: Birhanena Selam Printing Enterprise.

4. FDRE. (2009). Higher Education Proclamation (No.650/2009). Addis Ababa: Birhanena Selam Printing Enterprise.

5. Healey, N. M. (2008). Is higher education in really 'internationalising'? Higher Education, 55(3), 333-355.

6. Kahsay, M. N. (2012). Quality and quality assurance in Ethiopian higher education: Critical issues and practical implications.

7. Kassahun K. (2018). Status of Research in Ethiopian Higher Education Instituitions. Enhancing Quality of Education through Research, Community Services and Technology. Presented at the National Research Conference, Wolaita Sodo University.

8. Oyewole, O. (2009). Internationalization and its Implications for the Quality of Higher Education in Africa. Higher Education Policy, 22(3), 319-329. https://doi.org/10.1057/hep.2009.10

9. Saint, W. (2004). Higher education in Ethiopia: The vision and its challenges. Journal of Higher Education in Africa, 2(3), 83-113.

10. Sawyerr, A. (2004). African universities and the challenge of research capacity development. Jhea/Resa, 2(1), 211-240.

11. Wolaita Sodo University. (2016). Wolaita Sodo University Senate Legislation. unpublished working document, Wolaita Sodo University.

12. Yizengaw, T. (2005). Policy development in higher education in Ethiopia and the role of donors and development partners. International Expert Meeting-Formulas That Work: Making Higher Education Support More Effective. 